\title{
The European Territorial Cooperation as the Tool for Europe's Integration: Example of Latvia - Belarus Cross - Border Cooperation
}

\author{
Janis Balodis \\ Corvinus University of Budapest (Hungary), Institute of Sociology and Social Research and University of Ljubljana \\ (Slovenia), Faculty of Social Sciences
}

\begin{abstract}
The European Territorial cooperation is important part of the EU regional policy. It examines the relationships between countries and territories. Cross border cooperation is an institutional and a political oriented cooperation between two or more administrative and sovereign units. In this paper cross border cooperation was analysed as an institutional process of interstate cooperation and cross border cooperation between administrative units in Belarus - Latvia's borderland. European integration and cross border cooperation are linked by 1) integrated economic space across the member states by Henk van Houtum, 2) the intersection between the history of European integration and the more general research field of border studies by Birte Wassenberg and 3) more gradual process and impact on border locations after the Second World war by Steven Brakman, Harry Garretsen, Charles van Marrewijk and Abdella Oumer. The theoretical approach of cross border cooperation includes - 1) the relation between core and periphery, 2) the division of exogenous and endogenous factors and 3 ) types of borderlands (alienated borderlands, co - existent borderlands, interdependent borderlands and integrated borderlands). Further theorethical concepts are drivers of cross-border co - operation (economic, political leadership, identity/cultural and geographical drivers). The research question is - "How cross - border cooperation can influence the integration and cooperation between Latvia and Belarus? How far cooperation with an EU neighbour takes on hegemonic traits or not? Which are the cross border cooperation forms between Belarus and Latvia which "makes" the integration between Belarus and Latvia".
\end{abstract}

Keywords: The European Territorial Cooperation, Cross border cooperation, Latvia, Belarus, Eastern Partnership

\section{Introduction}

"Cross Border Cooperation (CBC) is one of the tools of the EU policy towards its neighbours. Cross border cooperation between two or more countries includes aspects of borderland development, regional integration, economic development and social cohesion"1.

"The regional integration has a historical background. In this sense cross border cooperation is understand as cooperation between border regions. Markus Perkmann are arguing, that "borders is a form of boundary associated with the rise of the modern nation - state"2 and the "establishment of an interstate geopolitical order'3 Tripathi Dhananjay"4.

"The main problem is to analyse, how between two regulation periods (2007 - 2013) and (2014 - 2020) of Neighbourhood and Partnership Instrument (ENPI), cross border cooperation influenced 'the cooperation between the EU member states and European Neighbourhood countries ${ }^{5}$ by Mirela Xheneti, David Smallbone and Friederike Welter. In this case, will be

\footnotetext{
1 Janis Balodis, Cross - Border Cooperation as the Tool for Europe's Integration: Example of Latvia - Belarus Cross - Border Cooperation, University of Latvia 74. Scientific Conference, Riga, Latvia, 2016, p. 78.

2 Markuss Perkmann, Cross-border regions: Results of regionalization of cross-border cooperation in Europe (1958-2007), in: Documents d'Analisi Geografica, 2010, pp. 21 - 40.

3 Tripathi Dhananjay, Energy Security: The Functional Area of Regional Cooperation for South Asia, 2011, Available at: https://srch.slav.hokudai.ac.jp/publictn/eurasia_border_review/Vol32/tripathi.pdf (Conducted on 14.02.2016).

4 Janis Balodis, Cross - Border Cooperation as the Tool for Europe's Integration: Example of Latvia - Belarus Cross - Border Cooperation, University of Latvia 74. Scientific Conference, Riga, Latvia, 2016, p. 78.

${ }^{5}$ David Smallbone Friederike Welter and Mirela Xheneti, Cross-Border Entrepreneurship and Economic Development in Europe's Border Regions, Cheltenham, Edward Elgar Pub, 2012, p. 94.
} 
set the analysis of the case study between Latvia and Belarus become a crucial topic for the European Neighbourhood Policy (the ENP), because it is unclear how member states between the EU and the ENP"1:

Cooperates between each other;

Makes partnership of social and economic development projects;

Encouraging civil society

A research problem is to compare cross - border cooperation concept to Europe's integration, especially at borderland regions and particular research question is: "How far does cross-border cooperation between a member and a non-member state at the case of Latvia-Belarus generate integration processes comparable to European Integration?". "Cross - border cooperation plays the role of Europe's integration, because cross border cooperation is the tool for territorial and administrative integration of Europe. Cross border cooperation had been seen as a consensus making policy between Latvian and Belarusian governments. Cross border cooperation is also political dialogue for municipal, regional and national inter - institutional cooperation"2.

\section{Theoretical analysis of the interaction between cross - border cooperation and integration}

\section{European Territorial Cooperation}

European Commission says, that European territorial cooperation: "is one of the two goals of cohesion policy and provides a framework for the implementation of joint actions and policy exchanges between national, regional and local actors from different Member States"3. European territorial cooperation leads regional policy, which solve the efficiency of local governance. Harald Bardersheim and Lawrence E. Rose says: "With respect to territorial choice, reasons given for boundary changes (usually amalgamations) or other measures are often that existing units are inefficient, are incapable of providing services and welfare"4.

\section{Forms of European Territorial Cooperation:}

Cross border cooperation - "directly neighbourly cooperation in all areas of life between regional and local authorities along the border and involving all actors" 5 ;

Trans - national cooperation - "cooperation (between regional and local authorities) mostly in single sectors (not in all areas of life) and with selected actors"6;

Interregional cooperation - "cooperation between countries (sometimes allowing regions to participate) with regard to a special subject (for example regional development) related to large, connected areas"7;

Table 1: "Modes of inter - regional cooperation"8

\begin{tabular}{|l|l|}
\hline "Hegemon" & "Regime" \\
Hierarchic & Common Regulatory \\
Conditionality & Bodies \\
\hline "Consultancy" & "Support" \\
Information & Assistance for Implementation \\
\hline
\end{tabular}

\footnotetext{
1 Janis Balodis \& Mikelis Jakunovs. Knowledge economy impact of regional development in Latvia - Russia - Belarus borderlands. The RSA Early Career Conference, Manchester, United Kingdom, 2013, pp. 34 - 42.

2 Janis Balodis, Social Entrepreneurship in the Borderland areas: Example of Valka/Valga border, Master thesis, 2015, p. 34.

${ }^{3}$ European Commission, Interreg : European Territorial Co-operation, 12 May, 2015, Available at:

http://ec.europa.eu/regional_policy/en/policy/cooperation/european-territorial/ (Consulted on 16.12.2015).

${ }^{4}$ Harald Baldersheim and Lawrence E. Rose, „Territorial Choice: Rescaling Governance in European States”, in: H. Baldersheim and L.

E. Rose, Territorial Choice - The Politics of Boundaries and Borders, Palgrave Mcmillan, 2010, pp. 1- 20.

${ }^{5}$ European Commission, Practical Guide to Cross-border Cooperation, Association of

European Border Regions (AEBR), Gronau, 2000, p. 24.

${ }^{6} \mathrm{lbid}$;

7 lbid;

${ }^{8}$ Bernhard Zeilinger, „The EU's external policy towards Eastern Europe on kigration issues”, in: W. Stamuller and K. Backmann, The EU's Shifting Borders - Theorethical approaches and policy implications in the new neighbourhood Routledge, London and New York, 2012, pp. 60 - 79.
} 
Exchange

Hegemonic inter - regional cooperation means dominant inter - regional cooperation, which is the leading mode from inter - regional cooperation (see: Tab.1). For example Schleswig - Holstein federal land region is more important, than Southern Denmark, because Schleswig - Holstein federal land can to attract more investments and support from German government. Consultancy is the channel for the coordination of inter - regional cooperation. Regime is the level of possible speed of inter - regional cooperation, which means how fast cross - border cooperation will be organixzed. Support of inter - regional cooperation means institutional and financial support of inter - regional cooperation, which is important for economic independence for cross - border cooperation.

\section{Cooperation outside of the EU;}

Cooperation outside of the EU means interregional and cross - border cooperation in the regions, which are outside from the EU, but which are bordered with the EU. There exist two particular financial instruments for realization of cooperation outside of the EU. These financial instruments are:

The Instrument for Pre-Accession Assistance (IPA) - "is based on partnerships with the EU candidate countries - the former Yugoslav Republic of Macedonia, Croatia, and Turkey - and potential candidate countries - Albania, Bosnia and Herzegovina, Montenegro, and Serbia. It supports administrative, social and economic reforms, as well as regional and cross-border co-operation"1.

The European Neighbourhood and Partnership Instrument (ENPI) - "promotes co-operation and economic integration between the EU and partner countries - Algeria, Armenia, Azerbaijan, Belarus, Egypt, Georgia, Israel, Jordan, Lebanon, Libya, Moldova, Morocco, the Palestinian Authority, the Russian Federation, Syria, Tunisia, and Ukraine. It supports partnerships encouraging good governance and social and economic development"2.

The financial assistance for the Instrument for Pre-Accession Assistance (IPA) and the European Neighbourhood and Partnership Instrument (ENPI) are accordingly "11, 7 billion EUR, of which 242 million EUR is earmarked for cross-border cooperation (IPA) and 15.4 billion EUR, of which 634 million is earmarked for cross-border cooperation"3.

European grouping of territorial cooperation;

"The European Grouping of Territorial Cooperation (EGTC) is a new tool, which has been presented by the European Commission on the basis of long-term political actions and proposals coming, among others, from the Committee of the Regions"4.

\section{Data and methodology}

In this research will be used -1) qualitative and 2) quantitative methodology. As a qualitative methodology will be used literature analysis and structural interviews with policy makers, members from civil society and diplomats. The interviews will be organized in Latvia and Belarus.

Data will be collected be collected data from Latvia - Lithuania - Belarus cross border cooperation data basis. Results from the interview will be used as the data for qualitative analysis. "Spatial data are those data which combine attribute information (e.g. name of the spatial object - for example villages, population density etc.) with location information (spatial coordinates) (georeferenced data)"5. Spatial data will used to proof geographical integrity of cross border cooperation.

Types of spatial data:

\footnotetext{
${ }^{1}$ European Commission, Regional development co-operation programmes outside the EU, 2016, Available at:

http://ec.europa.eu/regional_policy/lv/policy/cooperation/european-territorial/outside-the-eu/ (Conducted on 20.02.2016).

$2 \mathrm{lbid}$;

$3 \mathrm{lbid}$;

"European Union, The European Grouping of Territorial Cooperation (EGTC): state of play and prospects, 2009, Available at: http://cor.europa.eu/en/documentation/studies/Documents/EGTC-state-of-play/EGTC-state_of_play_and_prospects_EN.pdf (Conducted on 21.02.2016).

${ }^{5}$ Eric Marcon and Florence Puech, Measures of the geographic concentration of industries: improving distance-based methods, in: Journal of Economic Geography, Vol. 10, No. 2, 2010, pp. $745-762$.
} 
- "Point data: a single point location, such as a GPS reading or a geocoded address"1. For example - Houses, firms;

- "Line data (arcs): a set of ordered points, connected by straight line segments. For example - Roads, rivers"2;

- Polygonal data: For example an area, marked by one or more enclosing lines, possibly containing holes.

The next quantitative tool (the method) will be the geographical information systems (the GIS). As a specific computers program will be used ArcMap 10.3 and ArcMap Pro programs.

\section{Political integration between Latvia and Belarus provides closer cross - border cooperation between both countries}

Political integration between Latvia and Belarus provides closer cross - border cooperation between both countries. In this chapter will be provided - 1) the analysis of institutional framework of cross - border cooperation between Belarus and Latvia, 2) drivers of cross-border co - operation in Belarus and Latvia's borderland and 3) project analysis of European Neighbourhood and Partnership Instrument 2007-2013 Cross Border Cooperation Programme Latvia - Lithuania - Belarus.

Latvia and Belarus 'established diplomatic relationships in 1992, which was the start point of the cooperation between both countries' ${ }^{\prime}$. In the same year Belarus became as an important regional player in Eastern Europe, because Belarus started it's regional integration on Europe's political map. Famous Belarusian historian Jan Zaprudnik says, that: "Through diplomatic contacts with the European states, Minsk is trying to enter the European Community, with whose world contacts and culture Belarus feels more at home. On January 30,1992, the Republic of Belarus was accepted as a member of the Conference on Security and Cooperation in Europe"4. A very important field, where Latvia and Belarus are cooperating, is economy. Cross - border cooperation in the framework of institutional cross border cooperation defines as a "policy promoting all types of negotiated actions between the public institutions of at least two neighbouring territorial entities" The economic cooperation between Latvia and Belarus is organized by sub - institutions, like:

Latvian - Byelorussian Economic cooperation committee;

A Business club of the Embassy of Latvia in Minsk;

A promotional society of Latvian - Byelorussian economic relationship;

Latvian - Byelorussian business forum;

A very strong form of cross border cooperation between Latvia and Belarus is fighting against the human trafficking. Latvia as a country which eastern border (between Russia and Belarus) is a whole of the EU border and means that European Neighbourhood policy (see: Fig.2) is a crucial issue for Latvia. Between 2013 and 2014, Latvia's - Belarus border crossed 83 Vietnamese illegal immigrants. Trafficking is a challenge for the border guards and security at itself in both countries and specially in the borderlands. From Latvia's side, responsible institutions are: The Office of Citizenship and Migration Affairs (OCMA), Ministry of the Interior, Office of State Border Guard and Societal Integration Bureau. From Belarus side, responsible institutions are Belarusian state border guard committee and the Ministry of Internal Affairs of the Republic of Belarus.

Belarus is a part of the Eastern Partnership. The civil societal sector is important actor for cross border cooperation, especially for the projects, which are related "The Belarusian National Platform is organized differently than the National Platforms of other EaP countries which is also due to the different situation within the country and the limited participation of Belarus within the Eastern Partnership"6. This is related with political situation in Belarus, which is not democracy Western European point of view.

\footnotetext{
1 Gilles Duranton and Henry G. Overmant, Testing for Localization Using Micro - Geographic Data, in: Review of Economic Studies, Vol. 72, No. 3, 2005, pp. $1077-1106$.

2 Roberto Basile, Some notes on Spatial Statistics and Spatial Econometrics, Lecture material, Roma, 2013.

3 Latvijas Republikas Ārlietu Ministrija, Latvijas Republikas un Baltkrievijas Republikas divpusējās attiecības, 2016, Available at: http://www.mfa.gov.lv/arpolitika/divpusejas-attiecibas/latvijas-un-baltkrievijas-attiecibas (Consulted on 20.01.2016).

${ }^{4}$ Jan Zaprudnik, Belarus - At a Crossroads in History, Boulder, San Francisko, Westview Press, 1993, p. 212.

${ }^{5}$ Jean Baptiste Harguinde Guy and Katy Hayward, The Institutionalization of the European Internal Cross-Border Co-operation Policy: A First Appraisal, in: European Planning Studies, Vol. 22, No. 1, 2014, pp. 184 - 203.

${ }^{6}$ Eastern Partnership Civil Society Forum, Belarus, 2016, Available at: http://eap-csf.eu/en/national-platforms/belarus/ (Consulted on 21.01.2016).
} 
Latvia is part of the EU Baltic Sea region, where Belarus is available to participate for the EU strategy for Baltic Sea region (EUSBSR). EU Strategy for the Baltic Sea Region (EUSBSR) is related with "the EU Economic Development Strategy (Multi-Annual Financial Framework 2014-2020), such as mobility and multimodality, knowledge society, competitiveness, people and skills and institutional capacity and cooperation"1. Economic institutions in all three Baltic states are different from the market or the firm, and although they are an expression of local attitudes towards for example "associationism".

\section{The area of research}

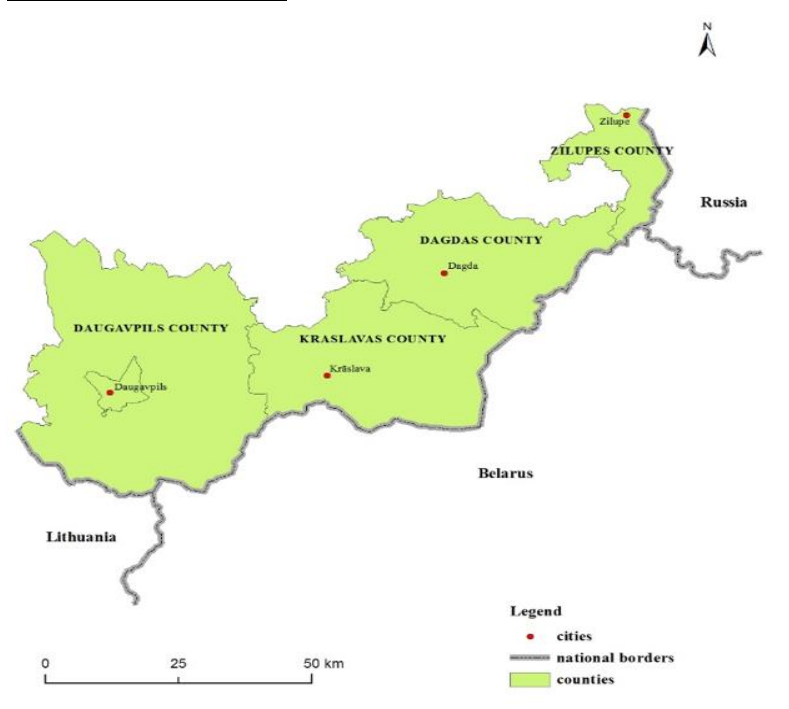

Figure 1: Counties from Latvian border side, which are bordered with Belarus - Latvia's border (Daugavpils, Krāslavas, Dagdas and Zilupes counties) (The author of map: Janis Balodis. The map is made in geographical information systems)

The research area is covered between borderland administrative units in Belarus and Latvia. In 2007, when cross border cooperation between Latvia and Belarus started, cross border cooperation existed between "old" administrative units regions (Russian raions; Latvian: rajons) (see: Fig. 1). In Latvian side were three regions - Daugavpils, Krāslavas and Ludzas regions (rajoni). In 2009, in Latvia was a new administrative reform, which changed an administrative division.

In Daugavpils county are three parishes, which are bordered with Belarus - Latvia's border. These parishes are: Demenes, Skrudlienas and Salienas parishes. These parishes are in the same size like before administrative reform in 2009. That shows, that administrative cooperation is the same as it was for the realization of cross border cooperation program for period

In Kraslavas county are four parishes, which are bordered with Belarus - Latvia's border. These parishes are Kaplavas, Indras, Kalniešu and Robeznieku parsihes. All parishes, which were mentioned before, existed also in "old" administrative reform.

In Zilupes county, which before was included in Kraslavas region, is only one administrative parish which bordered with Belarus - Latvia's border. It is Pasienes parish.

All administrative units from Latvian side are bordered with Braslaw, Verkhnyadzvinsk and Myory districts from Belarussian side.

\section{The integrity between cross - border projects in Latvia and Belarus}

\footnotetext{
1 European Parliament, Directorate - General for Internal Policies, Policy Department, Structural and Cohesion Policies, New Role of Macro Regions in European Territorial Cooperation, 2015, Available at: http://www.balticsea-regionstrategy.eu/attachments/article/590691/IPOL_STU(2015)540349_EN.pdf (Consulted on 26.01.2016). 
Projects of European Neighbourhood and Partnership Instrument 2007-2013, which is for cross border cooperation programme Latvia - Lithuania - Belarus. The analysis of cross - border projects between Latvia, Lithuania and Belarus by it's priority, shows integrity by different kind of projects and forms of cooperation.

5.1. Projects of European Neighbourhood and Partnership Instrument 2007-2013 Cross Border Cooperation Programme Latvia - Lithuania - Belarus

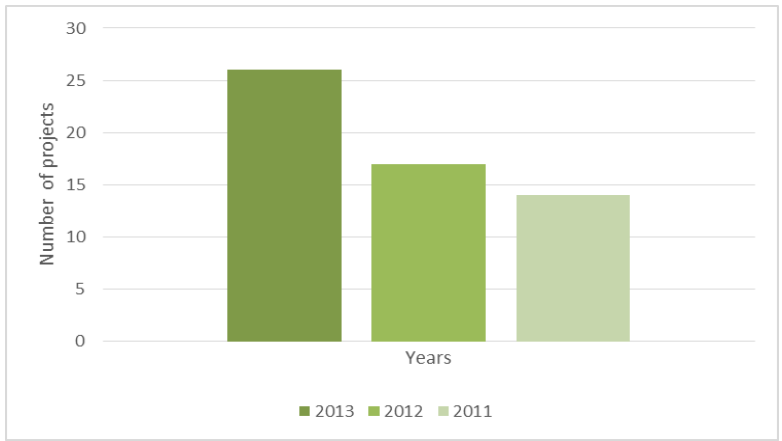

Figure 2: The number of projects between Latvia, Lithuania and Belarus for time period 2011 - 2013 ${ }^{1}$

The number of projects between Belarus, Lithuania and Latvia for period 2011 - 2013 is 57 projects (see: Fig. 2). There is a positive progression of the number of projects of cross border cooperation between Belarus, Lithuania and Latvia, for example in 2011 was 14 projects, but in 2013 the number of projects was 27.

\subsection{The number of cross - border projects in Latvia's - Belarus borderland (in border counties)}

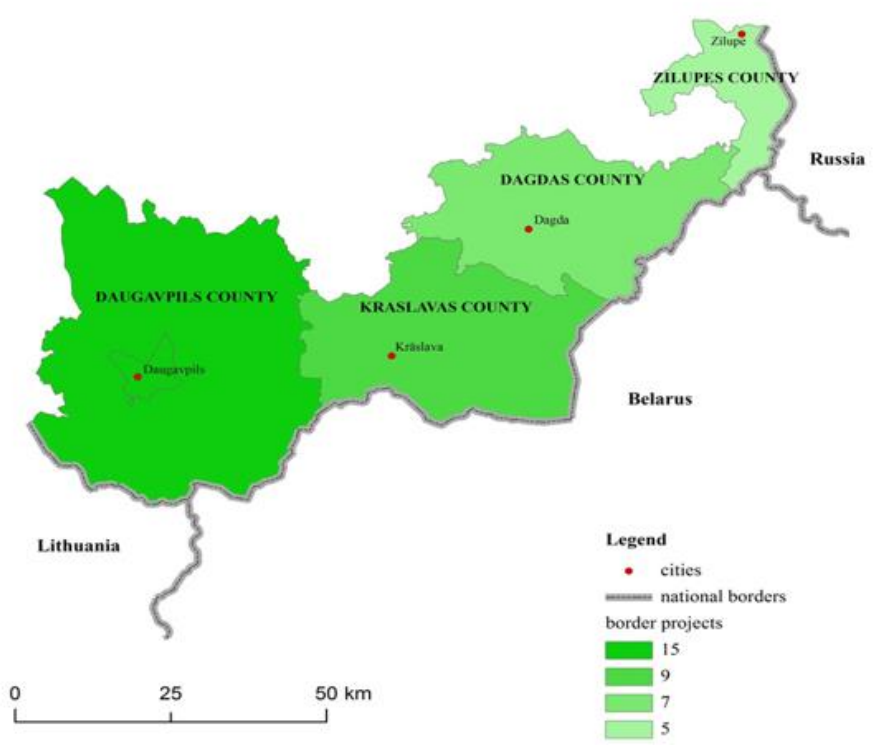

1 European Neighbourhood and Partnership Instrument 2007-2013 Cross Border Cooperation Programme Latvia - Lithuania - Belarus, Projects by Priority and Measure, 2016, Available at: http://www.enpi-cbc.eu/go.php/eng/projects/659/2/179 (Conducted on 27.02.2016). 
Figure 4: The number of cross - border projects in Latvia's - Belarus borderland (in border counties). The map is made by Janis Balodis using spatial data from geographical information data, which produced by Latvian Geospatial Data Agency.

Cross - border cooperation projects is not understand only from it's geographical meaning of cross - border regions. That also shows, that the majority of cross - border projects are not done in the borderland between Belarus and Latvia (see: Fig. 4). The institutions and responsible authorities in the borderland are more dependent from central administrative authorities - 1) regional government and 2) central government of county. The dynamics of cross - border projects in borderlands is hard to evaluate, because there is only data for the period $2007-2013$. The cross - border projects for the period $2014-2020$ is not finished yet.

\section{Cross border cooperation and integration at municipal level between Latvia and Belarus proof's a local integration in a local scale}

Cross border cooperation and integration at municipal level between Latvia and Belarus are organized by cross border cooperation programs and interstate cooperation in trade, economics and environment. It is also related for rural level between Belarus and Latvia.

In this chapter will be explained how two cross - border cities like Daugavpils (Latvia) and Vitebsk (Belarus) cooperates between each other. The next level at rural level, two villages - Druya (Belarus) and Piedruja (Latvia).

\subsection{The cross border cooperation in the municipal level, like the cooperation between Daugavpils and Vitebsk}

Table 2: Social geographical indicator comparison between Daugavpils and Vitebsk ${ }^{1}$

\begin{tabular}{|l|l|l|}
\hline Indicator & Daugavpils & Vitebsk \\
\hline Population (2015) & 96,818 & 366,299 \\
\hline Population density & $1,300 / \mathrm{km} 2$ & $2,900 / \mathrm{km} 2$ \\
\hline Area $\left(\mathrm{km}^{2}\right)$ & $72.48 \mathrm{~km} 2$ & $124.54 \mathrm{~km} 2$ \\
\hline Ethnical diversity (Latvians/Belarusians/\%) & $7,4 \%$ - Belarusians & $90 \%$ - Belarusians \\
& $18 \%$ - Belarusians & $1 \%$ - Latvians \\
\hline
\end{tabular}

The border as a part of cross - border cooperation provides two dimensions: "1) geographical location and product innovation"2.

The cross border cooperation in the municipal level shows cooperation linkage in a macro and micro level (see: Tab. 2). A macro level cooperation of cross border cooperation in the municipal level means, that a urban spaces (towns) cooperates between each other. Usually these cities are characterized in two terms: 1) border towns and 2) divided cities. For example cross border cooperation between Gorlitz (Germany) and Zgorzelec (Poland). A micro level cooperation is between of cross border cooperation in the municipal level means that urban districts cooperate between each other. For example, here as an example could be cross border cooperation between Vitorazska district between Gmund (Austria) and Česke Velenice (Czech Republic/Czechia).

But in Daugavpils and Vitebsk case, cross - border cooperation is not understand as a cross - border cooperation between Daugavpils and Vitebsk shows historical, geographical, economic (development) dimension of cross border cooperation or even partnership between Daugavpils and :

Historical dimension - Daugavpils and Vitebsk historically were located in one administrative unit - called Vitebsk governorate.

Geographical dimension - both cities are crossed by Daugava river. Also Daugavpils and Vitebsk are located on the highlands and the river valleys.

Economic (development) dimension - bilateral economic cooperation is organized between Latgale Planning region and Vitebsk region.

\footnotetext{
1 Gunta Šustere, Latvijas ǵeogrāfija 9. klasei. Mācību grāmata, Rīga, Zvaigzne ABC, 2011, p. 62.

2 Kirk S. Bowman, "The U.S. - Mexican Border as Locator of Innovation and Vice", in: P. Gangster and D.E. Lorey (ed., Borders and Border Politics in a Globalizing World, SR Books, Lanham and Boulder, 2005, pp. 269 - 284.
} 
Identity dimension is different from historical and geographical dimensions, because identity is related with behavioural geography. Alberto Gasparini talking about culture in the border towns, says: "The culture pervading the border town is founded on a basic ambiguity: on one hand it gives the border area and town is a feeling of marginality with respect to the state system"1.

\section{Cross border cooperation and cultural integration and identity between Latvia and Belarus}

Cross border cooperation and cultural integration and identity between Latvia and Belarus shows, how important is a unique identity for borderlands and cross - border relationships.

In this chapter will be explained a historical interlink between urban and rural places in Latvia's - Belarus borderland. This is versus for cultural geographical analysis for instance, how languages like Latvian and Belarusian. Ethnicities and religion are also two components, which are relevant for cross border culture.

\subsection{Historical - cultural identity of cross - border cooperation between Latvia and Belarus}

A borderland is one of the changeable "territorial items" in Belarus. Andrew Savchenko says, that: "In Belarus, borderland is not an abstract category"2. The borderlands of Belarus means a 'multicultural border, where are Slavic, Baltic and as well Jewish interaction were represented'3.

Table 3: James V. Wertsch's Voices of Collective Remembering ${ }^{4}$

\begin{tabular}{|l|l|}
\hline History & Collective Memory \\
\hline "Objective"5 & "Subjective"6 \\
\hline "Distanced from any particular perspective"7 & "Single committed perspective"8 \\
\hline "Reflects no particular social framework"9 & "Reflects a particular group's social framework"10 \\
\hline "Critical, reflective stance"11 & "Unself - conscious"12 \\
\hline "Recognises ambiguity"13 & $\begin{array}{l}\text { "Impatient with ambiguity about motives and the interpretation of } \\
\text { events"14 }\end{array}$ \\
\hline "Focus on transformation"15 & "Focus on stable, unchanging group essence"16 \\
\hline "Focus on historicity"17 & "Details of "pastness" of events"18 \\
\hline "Differentiates the past from the present"19 & "Links the past with the present"20 \\
\hline
\end{tabular}

\footnotetext{
${ }^{1}$ Alberto Gasparini, "Belonging and Identity in the European Border Towns: Self-Centered Borders, Hetero-Centered Borders", in: Journal of Borderlands Studies, Vol. 29, No. 2, 2014, pp. 165 - 201.

${ }^{2}$ Andrew Savchenko, Belarus - A Perpetual Borderland. Leiden, Boston, Brill, 2009, p. 1.

${ }^{3}$ Andrew Wilson, Belarus The Last European Dictatorship, New Haven and London, Yale University Press, 2011, p. 11.

${ }^{4}$ Paul Holtom, From Konigsberg to Kaliningrad: A Journey through the Politics and History and Memory, in: Eero Medijainen and Olaf Mertelsmann, Border Changes in 20th Century Europe, Lit Verlag Dr. W. Hopf, Berlin, 2010, pp. 271 - 296.

5 Ibid, p. 273.

6 lbid, p. 273.

7 lbid, p. 273

8 lbid, p. 273.

9 lbid, p. 273.

$10 \mathrm{lbid}$, p. 273.

11 lbid, p. 274.

12 lbid, p. 274.

13 lbid, p. 274.

14 lbid, p. 274.

15 lbid, p. 274.

16 lbid, p. 274.

17 lbid, p. 274.

18 lbid, p. 274.

19 lbid, p. 274.

20 lbid, p. 274.
} 


\begin{tabular}{|l|l|}
\hline "Views past events as taking place "then and not now"'1 & "Ahistorical, antihistorical"2 \\
\hline "Historical voice"3 & "Commemorative voice"4 \\
\hline "Museum as form"5 & "Museum as temple"6 \\
\hline $\begin{array}{l}\text { "Disagreement, change, and controversy as part of ongoing } \\
\text { historical"7 }\end{array}$ & "Unquestionable heroic narratives"8 \\
\hline
\end{tabular}

Paul Holtom is arguing, that collective membering is related with the history and a collective memory. There are various factors of how collective membering is described for geographical borders and borderlands. Factors like 1) objective, 2) distanced from any particular perspective and 3) critical and reflective stance are transformed to equality (see: Tab. 3). On the other hand for history, the factors are transformed from collective memory, like 1) subjective, 2) single committed perspective and 3) reflects a particular group's social framework. Subjective approach in history means that cross border phenomena is interpreted from a personal perspective and there is no relevance of cross border cooperation as a process of spatial mental interaction.

Historical - cultural identity of cross - border cooperation between Latvia and Belarus brings:

Memory;

"Borders exist everywhere, between life and death, between the believer and atheist, between the dweller and the neighbour and continue between the void and the fullness"9, mentioned Anjuman Ara Begum. Borderlands between Latvia and Belarus are those territories, where during the Second World war were the most important battles between Nazi Germany and Soviet Union.

Cultural diversity;

Multicultural region;

The relations between historical and cultural identity at the borderland is transforming to materiality. Karri Kiiskinen says, that: "The national and the EU border have mutual benefits when it comes to strategies of presenting cultural diversity. The ideas of a "multicultural region" suggest European values and these seem to be layered in the material heritage of the borderland"10. Cross - border cooperation among multicultural Latvia's - Belarus borderland

Cross - border cooperation provides also opportunities, for instance 'as spaces of connections, interdependencies and inter-regional cooperation'11.

\section{Conclusions}

The research question of master thesis is: "How cross - border cooperation can influence the integration and cooperation between Latvia and Belarus".

Cross - border cooperation as the tool of European integration is 1) dynamic, 2) complicated and 3) diverse. Cross border cooperation as the form of territorial cooperation is important for territorial integration. Institutions, common values, cooperation, synergy, unity and geographical space are elements for cross border cooperation.

Five possible hypothesis were analysed in this master thesis -1) Political integration between Latvia and Belarus provides closer cross - border cooperation between both countries. The cross - border cooperation builds a stronger intergovernmental cooperation between Latvia and Belarus, which is realized by the European Neighbourhood Policy

\footnotetext{
1 lbid, p. 274.

2 lbid, p. 274.

3 lbid, p. 274.

4 lbid, p. 274.

5 lbid, p. 274.

6 lbid, p. 274.

7 lbid, p. 274.

8 lbid, p. 274.

${ }_{9}^{9}$ Anjuman Ara Begum, "Women and the Heart of the Barbed Wire", in: Journal of Borderlands Studies, Vol. 27, No. 1, 2012, pp. 73 - 82.

10 Karri Kiiskinen, "Cultural Cooperation or Incorporation: Recollecting and Presenting Borderland Materiality at the External Border of the European Union", in: Journal of Borderlands Studies, Vol. 27, №. 3, 2012, pp. 315 - 329.

11 Filippo Celata, Raffaella Coletti. "Discourses and narratives of cross border cooperation and regionalism in the European Union ", Draft paper, 2012, pp. 1 - 12.
} 
Instrument, 2) The integrity between cross border projects in Latvia and Belarus, shows how both countries cooperates for economic, social affairs and combating against illegal immigration. A part of the bilateral cooperation between Latvia and Belarus, the cross border cooperation has been looking as the tool, how to promote the cooperation in business, culture, education, environmental protection and tourism between Latvia and Belarus, 3) Cross border cooperation and integration at municipal level between Latvia and Belarus proof's local integration in local scale. The cross border cooperation at the municipal level, like the cooperation between Daugavpils and Vitebsk shows oriented cooperation policy, 4) Cross border cooperation stimulates cultural integration between Latvia and Belarus. borderland between Latvia and Belarus is territory with it's own identity and culture and 5) There is existing institutional barriers between the integrity and cross - border cooperation. An institutional and organizational barriers for cross - border coopearation are significant problem cross border cooperation between Latvia and Belarus.

The cross - border cooperation builds a stronger intergovernmental cooperation between Latvia and Belarus has been proofed by following arguments. The cross border cooperation between Belarus and Latvia is organized as a cooperation for fields, like 1) economic development, 2) tourism, 3) trade, 4) environmental protection, 5) border security and 6) an intergovernmental cooperation. Mutual interests and common political - economic values bring together both countries and cross - border cooperation is looking as the solutions, how European integration works in practice. the European Neighbourhood Policy Instrument (The ENPI) is an good example how cross border cooperation programmes could integrate territories by a different level of economic development and sustainability of political regime. The number of projects between Belarus, Lithuania and Latvia for period 2011 - 2013 is 57 projects. There is a positive progression of the number of projects of cross border cooperation between Belarus, Lithuania and Latvia, for example in 2011 was 14 projects, but in 2013 the number of projects was 27. This shows, how cross - border projects are important for European integration phenomena in Belarus and Latvia's case.

Cross - border governance between Latvia and Belarus includes 1) multilevel governance, 2) trans border issues, 3) regional development and 4) governance research (which governance type for cross border cooperation is the best, for example good governance).

A part of the bilateral cooperation between Latvia and Belarus, the cross border cooperation has been looking as the tool, how to promote the cooperation in business, which is proofed in this research by three aspects 1) interstate aid policy for starting business, 2) Latvian - Belarusian business chamber and 3) business development policies from regional development institutions, for example an administration of Latgale Planning region (Latvia).

Cross border cooperation between Daugavpils and Vitebsk shows three dimensions, how urban entities like state significance cities like Daugavpils and Vitebsk cooperates between each other, using cross border cooperation approach. These dimensions are 1) historical, 2) economic and 4) geographical dimensions.

The borderland between Latvia and Belarus is territory with it's own identity and culture has been proofed by theoretical proof and practical field work in the research area.

In this research was used to elaborate cross border paradigms -1) realistic,2) transnational and 3) global.

A cross border identity was proofed by using cross border values. These values are 1) European added value, 2) political added value, 3) institutional added value, 4) socio - economic added value and 5) socio - cultural added value.

\section{Bibliography}

[1] Alberto Gasparini, "Belonging and Identity in the European Border Towns: Self-Centered Borders, HeteroCentered Borders", in: Journal of Borderlands Studies, Vol. 29, No. 2, 2014, pp. 165 - 201.

[2] Andrew Savchenko, Belarus - A Perpetual Borderland. Leiden, Boston, Brill, 2009, p. 1.

[3] Andrew Wilson, Belarus The Last European Dictatorship, New Haven and London, Yale University Press, 2011, p. 11.

[4] Anjuman Ara Begum, "Women and the Heart of the Barbed Wire", in: Journal of Borderlands Studies, Vol. 27, No. 1, 2012, pp. $73-82$. 
[5] Bernhard Zeilinger, „The EU's external policy towards Eastern Europe on kigration issues”, in: W. Stamuller and K. Backmann, The EU's Shifting Borders - Theorethical approaches and policy implications in the new neighbourhood Routledge, London and New York, 2012, pp. 60 - 79.

[6] David Smallbone Friederike Welter and Mirela Xheneti, Cross-Border Entrepreneurship and Economic Development in Europe's Border Regions, Cheltenham, Edward Elgar Pub, 2012, p. 94.

[7] Eastern Partnership Civil Society Forum, Belarus, 2016, Available at: http://eap-csf.eu/en/nationalplatforms/belarus/ (Consulted on 21.01.2016).

[8] Eric Marcon and Florence Puech, Measures of the geographic concentration of industries: improving distancebased methods, in: Journal of Economic Geography, Vol. 10, No. 2, 2010, pp. 745 - 762.

[9] European Commission, Interreg : European Territorial Co-operation, 12 May, 2015, Available at: http://ec.europa.eu/regional_policy/en/policy/cooperation/european-territorial/ (Consulted on 16.12.2015).

[10] European Commission, Practical Guide to Cross-border Cooperation, Association of European Border Regions (AEBR), Gronau, 2000, p. 24.

[11] European Commission, Regional development co-operation programmes outside the EU, 2016, Available at: http://ec.europa.eu/regional_policy/lv/policy/cooperation/european-territorial/outside-the-eu/ (Conducted on 20.02.2016).

[12] European Parliament, Directorate - General for Internal Policies, Policy Department, Structural and Cohesion Policies, New Role of Macro Regions in European Territorial Cooperation, 2015, Available at: http://www.balticsea-region (Consulted on 26.01.2016). strategy.eu/attachments/article/590691/IPOL_STU(2015)540349_EN.pdf

[13] European Union, The European Grouping of Territorial Cooperation (EGTC): state of play and prospects, 2009, Available at: http://cor.europa.eu/en/documentation/studies/Documents/EGTC-state-of-play/EGTCstate_of_play_and_prospects_EN.pdf (Conducted on 21.02.2016).

[14] Filippo Celata, Raffaella Coletti. "Discourses and narratives of cross border cooperation and regionalism in the European Union ", Draft paper, 2012, pp. 1 - 12.

[15] Gilles Duranton and Henry G. Overmant, Testing for Localization Using Micro - Geographic Data, in: Review of Economic Studies, Vol. 72, No. 3, 2005, pp. 1077 - 1106.

[16] Gunta Šustere, Latvijas ǵeogrāfija 9. klasei. Mācību grāmata, Rīga, Zvaigzne ABC, 2011, p. 62.

[17] Harald Baldersheim and Lawrence E. Rose, „Territorial Choice: Rescaling Governance in European States”, in: H. Baldersheim and L. E. Rose, Territorial Choice - The Politics of Boundaries and Borders, Palgrave Mcmillan, 2010, pp. 1- 20.

[18] Jan Zaprudnik, Belarus - At a Crossroads in History, Boulder, San Francisko, Westview Press, 1993, p. 212.

[19] Janis Balodis \& Mikelis Jakunovs. Knowledge economy impact of regional development in Latvia - Russia Belarus borderlands. The RSA Early Career Conference, Manchester, United Kingdom, 2013, pp. 34 - 42.

[20] Janis Balodis, Cross - Border Cooperation as the Tool for Europe's Integration: Example of Latvia - Belarus Cross - Border Cooperation, University of Latvia 74. Scientific Conference, Riga, Latvia, 2016, p. 78.

[21] Janis Balodis, Cross - Border Cooperation as the Tool for Europe's Integration: Example of Latvia - Belarus Cross - Border Cooperation, University of Latvia 74. Scientific Conference, Riga, Latvia, 2016, p. 78.

[22] Janis Balodis, Social Entrepreneurship in the Borderland areas: Example of Valka/Valga border, Master thesis, 2015, p. 34.

[23] Jean Baptiste Harguinde Guy and Katy Hayward, The Institutionalization of the European Internal Cross-Border Co-operation Policy: A First Appraisal, in: European Planning Studies, Vol. 22, No. 1, 2014, pp. 184 - 203. 
[24] Karri Kiiskinen, "Cultural Cooperation or Incorporation: Recollecting and Presenting Borderland Materiality at the External Border of the European Union", in: Journal of Borderlands Studies, Vol. 27, No. 3, 2012, pp. 315 329.

[25] Kirk S. Bowman, "The U.S. - Mexican Border as Locator of Innovation and Vice", in: P. Gangster and D.E. Lorey (ed., Borders and Border Politics in a Globalizing World, SR Books, Lanham and Boulder, 2005, pp. 269 -284 .

[26] Latvijas Republikas Ārlietu Ministrija, Latvijas Republikas un Baltkrievijas Republikas divpusējās attiecības, 2016, Available at: http://www.mfa.gov.Iv/arpolitika/divpusejas-attiecibas/latvijas-un-baltkrievijas-attiecibas (Consulted on 20.01.2016).

[27] Markuss Perkmann, Cross-border regions: Results of regionalization of cross-border cooperation in Europe (1958-2007), in: Documents d'Analisi Geografica, 2010, pp. 21 - 40.

[28] Paul Holtom, From Konigsberg to Kaliningrad: A Journey through the Politics and History and Memory, in: Eero Medijainen and Olaf Mertelsmann, Border Changes in 20th Century Europe, Lit Verlag Dr. W. Hopf, Berlin, 2010, pp. $271-296$.

[29] Roberto Basile, Some notes on Spatial Statistics and Spatial Econometrics, Lecture material, Roma, 2013.

[30] Tripathi Dhananjay, Energy Security: The Functional Area of Regional Cooperation for South Asia, 2011, Available at: https://src-h.slav.hokudai.ac.jp/publictn/eurasia_border_review/Vol32/tripathi.pdf (Conducted on 14.02.2016). 